\title{
A Study on PGDE Student-Teacher Efficacy Beliefs in the Sri Lankan Context
}

\author{
F.M. Nawastheen ${ }^{* 1}$, W.M.S. Wanasinghe ${ }^{1}$, P. Senaviratne ${ }^{2}$ \\ ${ }^{1}$ Department of Secondary \& Tertiary Education, Faculty of Education, The \\ Open University of Sri Lanka \\ ${ }^{2}$ Department of Early Childhood and Primary Education, Faculty of \\ Education, The Open University of Sri Lanka
}

\begin{abstract}
The main purpose of this study was to determine the self-efficacy beliefs of the student-teachers in the context of Sri Lanka. The respondents consisted of 471 student-teachers from seven study centres of Post Graduate Diploma in Education (PGDE) Programme of the Open University of Sri Lanka. The study employed an adapted questionnaire based on the Teacher Self-Efficacy Scale. Findings from the analysis showed that the self-efficacy of studentteachers in student engagement $(M=7.07, S D=.94)$, instructional strategies $(\mathrm{M}=7.4, \mathrm{SD}=.91)$ and classroom management $(\mathrm{M}=7.2, \mathrm{SD}=1.0)$ remained high. Outcomes from the t-test did not indicate significant differences between the male $(M=7.03, S D=.930 ; M=7.3, S D=.836 ; M=7.17, S D=1.03)$ and female $(M=7.09, \quad S D=.953 ; M=7.46, S D=.945 ; M=7.2, S D=.996) \quad P G D E$ student teachers in terms of student engagement, instructional strategies and classroom management. Findings from the one-way ANOVA showed a significant difference in student engagement based on the experience of teachers ( $F=3.4 ; d f=3.471 ; p=.018)$. No significant differences among other groups based on the medium of instruction and qualifications of the studentteachers were found. Approximately $78 \%$ of the student-teachers stated that they developed the knowledge and skills related to self-efficacy from the various subjects of the PGDE programme. The study suggests several strategies which need to be incorporated in the PGDE programme to enhance the self-efficacy of student-teachers in their teaching-learning process.
\end{abstract}

\footnotetext{
* Corresponding Author: F. M. Nawastheen; email: fmnaw@ou.ac.lk

ORCiD: http://orcid.org/0000-0001-9538-7372

(Received 21 March 2017; Revised 06 June 2017; Accepted 20 July 2017)

(c) OUSL
} 
Keywords: Teachers' self-efficacy beliefs, Instructional strategies, Student engagement, Classroom management

\section{Introduction}

Even when an educational system has good policies, educational goals, administrative practices and schools that provide all necessary resources and facilities, its success still depends on teachers. Thus, appointing qualified teachers and providing continuous professional training are extremely important. Moreover, to achieve educational goals, the professional development of all teachers should be ensured for high teaching quality, and teacher preparation and professionalism should be reinvented (DarllingHammond, 1990). Professional qualifications are one of the key elements in measuring the performance of teachers. Obtaining professional qualifications allows teachers to develop their individual skills and provides a good source of knowledge (Gunawardena, Rupasinghe \& Zoysa, 2010; Nawastheen, 2014). Therefore, professional development is extremely important to school teachers and it is an uptake of learning opportunities, which deepen and extend their professional competence, including knowledge, beliefs, motivation and self-regulatory skills (Richter, Kunter, Klusmann, Lüdtke, \& Baumert, 2011).

In Sri Lanka, various efforts have been made to enhance the careers of teachers. Their working environment has been improved, and their confidence and pride have been boosted by higher learning opportunities (Nawastheen, 2014). Efforts were initiated during the State Council period of Sri Lanka (1931-1947). The Postgraduate Diploma in Education (PGDE) was introduced in 1948 for teachers to obtain their first professional qualification. Distance education was introduced in 1976 by establishing the Sri Lanka Institute of Distance Education (SLIDE), which mainly focuses on providing courses in Mathematics, Science, Management and Technical Education to students at the tertiary level (Kotelawele \& Samarasundara, 1986). However, teacher-related courses, especially PGDE, in distance education were introduced with the establishment of the Open University of Sri Lanka (OUSL) in 1980 (Gonsalkorale, 2016). Subsequently, teacher professional development programmes which are offered by the OUSL, have become very popular in the open and distance education in Sri Lanka. In 2009-2015, a total of 21358 student teachers registered for various teacher professional development programmes at the Faculty of Education (FoE) of OUSL. Among 
them, 16411 (76\%) student teachers registered in the PGDE programme of the OUSL. These teacher education programmes aim to develop necessary pedagogical skills and content knowledge in teachers. These programmes develop the confidence of teachers in terms of their teaching and learning skills, thereby making their students successful in learning as well.

For 36 years, the OUSL has been conducting the PGDE programme, which aims to provide professional training to graduate teachers. This programme is extremely important given that many graduate teachers enter the teaching profession without teaching-related trainings. The PGDE programme is the first professional course for graduate teachers in Sri Lanka. Teachers learn educational concepts and undergo 10 weeks of continuous supervised teaching where they apply what they learned from the programme. Many young graduate teachers enrol every year in the PGDE programme to obtain professional qualification and become eligible for promotion to the next level in the teaching profession. Evaluating teachers is important to assess whether they are receiving necessary skills through the programme and applying their learning in classroom practices. In this context, investigating how teachers develop skills and beliefs from the programme is extremely important. Determining the efficacy of teachers after completing this programme is also important.

Teacher efficacy is the key indicator of the appropriateness and adequacy of the personal instructional preparedness of teachers. It can also serve as a warning of the critical problems faced by teachers (Chang, 2010) which can be addressed in future programmes. However, follow-up studies on the performance of teachers in the teaching and learning process after successfully completing the PGDE programme are unavailable. Such investigations on the self-efficacy of teachers will reflect how they gained confidence to perform activities in the teaching and learning process from the PGDE programme. Therefore, this study aimed to determine the selfefficacy of student teachers who finished their taught courses and first stage of teaching practice component of the PGDE Programme.

\section{Review of literature}

Self-efficacy is the belief of an individual in his/her ability to succeed in specific situations. Teacher efficacy is the belief of teachers in their abilities to organize and perform necessary activities to bring about desired results 
(Fives 2003; Tschannen-Moran, Woolfolk Hoy \& Hoy, 1998). Charalambous \& Philippou (2010) found that teachers with high efficacy beliefs are more willing to adopt innovations and experiment. Teachers are the central issue in discussions on educational aspects because they translate all educational policies into practice. Therefore, scholars consider teachers as the centrepiece (Charalambous \& Philippou, 2010), a significant agent (Ma, Yunpeng, Yin, \& Tang, 2009) or an individual agency (Flores, 2005) in an educational setting. Teachers are considered the centrepiece of educational change rather than mere executors of enforced policies (Charalambous \& Philippou, 2010). Furthermore, scholars postulate that the personal characteristics and capacities of teachers could affect curriculum reform implementation, including their subject matter and pedagogical knowledge, pedagogical design capacities, epistemological and pedagogical beliefs, efficacy beliefs, orientation toward the curriculum, professional identity and status, tolerance for discomfort, concerns and years of experience. Cerit (2010) suggested that the actions and behaviour of teachers are related to their beliefs, perceptions, assumptions and motivational levels. Therefore, research on the beliefs of teachers is important to organize teaching and define methods of understanding.

After Albert Bandura's Social Cognitive Theory (1977; 1997), teacher efficacy became popular in the field of educational research (Duffin, French, \& Patrick, 2011). According to Bandura (1983), the ability of an individual to perform his task refers to efficacy. In classroom practices, the ability of teachers to produce desired results is called teacher efficacy or teacher selfefficacy beliefs. Teacher self-efficacy belief, a personal characteristic, has gained much attention in recent years (Chang, 2010; Bandura, 1997). Numerous studies in recent years have focused on the importance of the selfefficacy concept in understanding the behaviour of teachers and students in the learning process (Arigbabu, Abayomi, \& Oludipe, 2009). A total of 218 empirical articles (published in 1998-2009) were examined for key characteristics and compared to those published in the previous 12 years (i.e. 1986-1997) (Klassen, Tze, Betts, \& Gordon, 2010).

Teacher self-efficacy has been examined with various other aspects and in different contexts. Teachers with high self-efficacy are able to produce desired results in the learning process particularly in the performance, achievements and motivation of the students. Teacher efficacy can affect the tasks of managing and motivating students, in that teachers with low self- 
efficacy might avoid planning activities that they believe exceed their capabilities, might not persist with students that have difficulties, might expend little effort into finding materials and might not teach content in ways that help students understand better (Kurz \& Knight 2003). Teachers with high self-efficacy are more likely to develop challenging activities, help students succeed and persevere with students who have trouble learning (Kurz \& Knight 2003). Studies on self-efficacy or the sense of efficacy of teachers have explored many fields of study and contexts, such as individual relationships, collective efficacy and goal (Kurz \& Knight 2003), collective efficacy at the classroom level (Putney \& Broughton, 2011), self-efficacy beliefs of novice and experienced teachers (Tschannen-Moran \& Woolfolk Hoy, 2007; Marshall, Horton, Igo, \& Switzer, 2007), self-efficacy of mathematics teachers (Marshall et al., 2007; Chang, 2010), self-efficacy of pre-service teachers (Cerit, 2010), self-efficacy of science teachers (Cantrell, Young, \& Moore, 2017; Smolleck, Carla \& Yoder, 2006; Arigbabu et al., 2009), self-efficacy and burn out in teaching (Friedman, 2003), teacher self-efficacy on the curriculum reform (McCormick \& Ayres, 2009; Charalambous \& Philippou, 2010) and self-efficacy on the technological pedagogical content (Lee \& Tsai, 2008). No related study was found in the search of the literature based on the self-efficacy of teachers in the context of Sri Lanka.

Various instruments have been developed to measure self-efficacy beliefs. For example, Gibson and Dembo (1984) developed the 30-item Teacher Efficacy Scale that uses a 5-point Likert scale, ranging from 'strongly agree' to 'strongly disagree.' Bandura (1997) also used a 30-item Teacher Efficacy Scale that uses a 9-point Likert scale, ranging from 'nothing' to 'a great deal.' In this instrument, teachers' efficacy was measured in terms of their influence in decision making, Influence on school resources, instructional self-efficacy, disciplinary self-efficacy, and efficacy to enlist parental involvement, efficacy to enlist community involvement and efficacy to create a positive school climate (Woolfolk Hoy \& Sperob 2005). Likewise, Tschannen-Moran and Woolfolk Hoy (2001) developed their own self-efficacy scale with 24 items on a 9-point Likert scale, ranging from 'nothing' to 'a great deal'. The development of efficacy scales boosted the studies on teacher efficacy. The efficacy scales measure the evaluations of people of their probability to succeed in teaching (Duffin et al., 2011). This instrument has two types: Teachers' Sense of Efficacy Scale (TSES) long (24 items) and TSES short (12 items). This instrument aims to evaluate three main teaching areas, namely, efficacy for efficacy to promote student engagement (SE), and efficacy in 
using instructional strategies (IS) and classroom management (CM). Student engagement refers to the efforts of the teachers in facilitating in terms of behavioural, cognitive and motivational engagement with students in the classroom (Linnenbrink \& Pintrich, 2010).

Self-efficacy is one important aspect to promote students' engagement and learning (Linnenbrink \& Pintrich, 2010). Similarly, Instructional strategies are techniques that teachers can use to facilitate the students to learn on their own. It is essential that teachers should enhance their knowledge and skills in various methods and techniques of teaching and assessment. Eight (8) items out of 24 of TSES are included to gauge the efficacy beliefs in instructional strategies. It measures teachers' ability in responding to students' questions, measuring student's comprehensions, and adjusting lessons to cater to individual learner needs, using various assessment skills, ability in explaining content in easy ways, using alternative strategies and providing challenges to the gifted students in classroom. To be a successful teacher, it is essential to develop skills and responsibilities related to maintaining classroom in order. Classroom management is described as providing and sustaining appropriate conditions in order for eliciting learning by making necessary arrangements of physical and other resources (Sivri \& Balcl, 2015). Efficacy in Classroom management is one important aspect of teachers' self-efficacies in general, and therefore, efficacy in classroom management was taken as a sub-domain in two of the major self-efficacy scales as in TSES instrument (Sivri \& Balcı, 2015). In addition, Duffin et al., (2011) stated that the TSES instruments were validated in many countries, including USA, Canada and Singapore; thus, these instruments are culture free and suitable in measuring teacher efficacy in any context.

\section{Methodology}

To find out accurate information regarding teachers' self-efficacy beliefs, this study was carried out as a survey using the TSES instrument (TschannenMoran \& Woolfolk Hoy, 2001; Woolfolk Hoy, n.d.). The aim of the study was to determine the self-efficacy beliefs of the student-teachers who completed their taught course in the PGDE degree programme of the Open University of Sri Lanka (OUSL).

The following research questions were formed: 
1. What is the self-efficacy of PGDE student teachers in their instructional strategies (IS), classroom management (CM) and student engagement (SE)?

2. Do the efficacy beliefs of PGDE student teachers differ in terms of their gender, medium of instruction, teaching experience and academic qualifications?

3. To what extent does the PGDE programme help in developing knowledge and skills in terms of IS, CM and SE in their teaching and learning process?

\section{Sample}

The study included 471 student teachers who were enrolled in the PGDE Programme in the Faculty of Education of the OUSL. A stratified random sample was used, which consisted of 274 Sinhala, 179 Tamil and 18 English medium teachers, as shown in Table 1. Given that the English medium programme is conducted only in the Colombo regional centre, the sample for the English medium was only from the Colombo regional centre. In addition, the sample also consisted of different types of teachers in terms of their experience and qualifications. Four teachers had less than one year experience and 270 teachers had 1- 5 years' experience. A total of 128 teachers had 6-10 years' experience whilst others had more than ten years of experience. Similarly, the respondents differed in terms of the highest level of their professional qualifications; there were teachers with postgraduate qualifications $(n=118)$, trained graduate teachers $(n=44)$, graduate teachers $(n=294)$, trained teachers from training colleges $(n=10)$ and teachers who have been trained at National Colleges of Education (NCOE) $(n=5)$.

Table 1: Sample based on Study Centres

\begin{tabular}{|c|c|c|c|c|c|c|}
\hline \multirow[b]{2}{*}{ Centre } & \multicolumn{3}{|c|}{ Medium of Teaching } & \multicolumn{2}{|c|}{ Gender } & \multirow[t]{2}{*}{ Total } \\
\hline & Sinhala & Tamil & English & $\mathrm{M}$ & $F$ & \\
\hline Colombo & 70 & 21 & 18 & 23 & 88 & 109 \\
\hline Jaffna & 0 & 76 & 0 & 31 & 45 & 76 \\
\hline Batticoloa & 0 & 55 & 0 & 21 & 34 & 55 \\
\hline Kurunegala & 77 & 0 & 0 & 20 & 57 & 77 \\
\hline Anuradhapura & 43 & 0 & 0 & 16 & 27 & 43 \\
\hline Matara & 56 & 0 & 0 & 15 & 41 & 56 \\
\hline Kandy & 28 & 27 & 0 & 15 & 40 & 55 \\
\hline Total & 274 & 179 & 18 & 141 & 330 & 471 \\
\hline
\end{tabular}




\section{Methods of data collection and analysis}

The study employed the TSES instrument of Tschannen-Moran and Woolfolk Hoy (2001), which consists of 24 items, to assess the three dimensions of teacher efficacy, namely, Instructional Strategies (8 items), Classroom Management ( 8 items) and Student Engagement ( 8 Items). The 24 items are rated on a Likert scale ranging from one to nine (Yeo, Ang, Chong, Huan \& Quek, 2008). According to Tschannen-Moran and Woolfolk Hoy (2007), this scale assesses using a 9-point scale continuum with anchors at 1 (nothing), 3 (very little), 5 (some influence), 7 (quite a bit) and 9 (a great deal). Yeo et al. (2008) stated that TSES has good internal consistency with Cronbach's alphas, which range from 0.81 to 0.86 . This instrument is available online at http://u.osu.edu/hoy.17/files/2014/09/TSES-+-scoring-zted8m.pdf.

The TSES instrument was adopted and translated into Sinhala and Tamil, which are the local national languages in Sri Lanka. Translated instruments were re-translated into English and ensured its validity. In addition, the instrument was piloted with 30 teachers and its Cronbach's alpha was calculated. Analysis of the pilot study showed that the Cronbach's alpha test values for all three domains of TSES were at acceptable levels ( $\mathrm{SE}=.786$, $\mathrm{IS}=.835, \mathrm{CM}=.828$ ).

The following seven open-ended questions were also added to find answers for the third research question of the study:

1. Do you think that the PGDE programme developed your knowledge and skills in instructional strategies?

2. If so, what are the subjects or courses of the programme which directly helped you to develop skills in Instructional strategies?

3. Do you think that the PGDE programme developed your knowledge and skills in engaging with students?

4. If so, what are the subjects or courses of the programme which directly helped you to develop skills in engaging with students?

5. Do you think that the PGDE programme developed your knowledge and skills classroom management strategies?

6. If so what are the subjects or courses of the programme which directly helped you to develop skills in classroom management strategies?

7. What are your suggestions for improving the PGDE programme with regard to developing your knowledge and skills on effective teaching? 
The data collected for research questions 1 and 2 were analysed using quantitative techniques. The mean and the standard deviation were determined from the TSES instrument data, and the overall teacher selfefficacy level was determined in the context of teaching and learning process. T-Test and one-way ANOVA were utilised to determine the differences based on the gender, medium of teaching, qualification and experience of the teachers. Moreover, responses for research question 3 were converted to quantitative measures in order to calculate percentage as there were common answers.

\section{Findings}

The findings from the analysis of the collected data are discussed according to the research questions of the study.

\section{What is the self-efficacy of student teachers in terms of IS, CM and SE?}

The first research question determines the overall self-efficacy of student teachers in terms of Instructional Strategies (IS), Classroom Management (CM) and Student Engagement (SE). The mean and standard deviation values were calculated based on the answers of the respondents to the TSES items. Table 2 shows the mean and standard values of the self-efficacy beliefs of the student teachers in terms of SE, IS and CM.

Table 2: PGDE Student Teachers' Self-Efficacy Beliefs

\begin{tabular}{|l|c|c|c|r|r|}
\hline & $\mathrm{N}$ & $\begin{array}{c}\text { Mean } \\
(\mathrm{M})\end{array}$ & $\begin{array}{c}\text { Std. Deviation } \\
(\mathrm{SD})\end{array}$ & Minimum & Maximum \\
\hline $\begin{array}{l}\text { Student } \\
\text { Engagement }\end{array}$ & 471 & 7.0799 & .94848 & 3.88 & 9.00 \\
\hline $\begin{array}{l}\text { Instructional } \\
\text { Strategies }\end{array}$ & 471 & 7.4342 & .91456 & 3.50 & 9.00 \\
\hline $\begin{array}{l}\text { Classroom } \\
\text { Management }\end{array}$ & 471 & 7.2381 & 1.00852 & 2.63 & 9.00 \\
\hline
\end{tabular}

The findings from the analysis showed that the teachers maintained high selfefficacy in their $\mathrm{SE}(\mathrm{M}=7.07 \mathrm{SD}=.94)$, IS $(\mathrm{M}=7.4, \mathrm{SD}=.91)$ and $\mathrm{CM}(\mathrm{M}=7.2, \mathrm{SD}=$ 1.0). The results clearly indicate that PGDE student teachers develop positive 
self-efficacy beliefs in terms of engaging with students, using appropriate instructional strategies and managing the classroom better.

Do the efficacy beliefs of PGDE student teachers differ in terms of their gender, medium of instruction, teaching experience and academic qualifications?

Independent t-test and one-way ANOVA were performed to answer this question. Table 3 shows the results based on the independence t-test analysis.

Table 3: Differences between Male and Female Teachers (Independent t-test)

\begin{tabular}{|l|l|c|c|c|}
\hline \multicolumn{1}{|c|}{$\begin{array}{c}\text { Demographic } \\
\text { Variable }\end{array}$} & $\begin{array}{l}\text { Aspects of Self- } \\
\text { Efficacy Beliefs }\end{array}$ & $\mathrm{t}$ & $\mathrm{df}$ & \multicolumn{1}{c|}{$\begin{array}{c}\text { Sig (2 } \\
\text { tailed) }\end{array}$} \\
\hline $\begin{array}{l}\text { Gender of PGDE } \\
\text { Student } \\
\text { Teachers }\end{array}$ & $\begin{array}{l}\text { Student } \\
\text { engagement }\end{array}$ & -.628 & 268.429 & .530 \\
\cline { 2 - 5 } & $\begin{array}{l}\text { Instructional } \\
\text { strategies }\end{array}$ & -1.167 & 296.947 & .244 \\
\cline { 2 - 5 } & $\begin{array}{l}\text { Classroom } \\
\text { management }\end{array}$ & -.828 & 255.083 & .408 \\
\hline
\end{tabular}

As shown in Table 3, no significant difference was observed between the male $(M=7.03 S D=.930)$ and the female $(M=7.09, S D=.953)$ PGDE student teachers in SE. Likewise, no significant difference was observed between the male $(M=7.3 S D=.836)$ and the female $(M=7.46, S D=.945)$ PGDE student teachers in their IS. No significant difference was found between the male $(M=7.17 \mathrm{SD}=1.03)$ and the female $(M=7.2, S D=.996)$ PGDE student teachers in their CM. The results indicate that teachers in the PGDE programme develop their knowledge and skills equally in terms of engaging with the students, planning and utilising appropriate instructional strategies and managing the classroom regardless of their gender.

One-way ANOVA was performed to determine the differences in their selfefficacy beliefs based on their medium of teaching, teaching experience and qualifications. Table 4 shows the results of the one-way ANOVA analysis. A significant difference in $\mathrm{SE}$ based on the experience of teachers $(\mathrm{F}=3.4 ; \mathrm{df}=3$; $p=.018)$ was observed. The mean values are: less than one year $=6.2 ; 1-5$ years $=6.9 ; 6-10$ years $=7.2$; more than 10 years $=7.2$. Therefore, teachers 
with longer experience engage with their students better than other teachers. The one-way ANOVA analysis revealed that there was no significant difference among the other groups based on medium of instruction and qualifications.

Table 4: Analysis of One-Way ANOVA on the Variables: Medium of Instruction, Teachers' Experience and Qualifications

\begin{tabular}{|c|c|c|c|c|c|c|}
\hline Variable & $\begin{array}{l}\text { Aspects of Self- } \\
\text { Efficacy beliefs }\end{array}$ & $\begin{array}{l}\text { Sum of } \\
\text { Squares }\end{array}$ & $d f$ & $\begin{array}{l}\text { Mean } \\
\text { Square }\end{array}$ & $\mathrm{F}$ & $p$ \\
\hline \multirow{3}{*}{$\begin{array}{l}\text { Medium of } \\
\text { Teaching } \\
\text { (Sinhala, Tamil } \\
\text { \& English }\end{array}$} & $\begin{array}{l}\text { Student } \\
\text { engagement }\end{array}$ & 4.497 & 2 & 2.249 & 2.516 & .82 \\
\hline & $\begin{array}{l}\text { Instructional } \\
\text { Strategies }\end{array}$ & 1.842 & 2 & .921 & 1.101 & .333 \\
\hline & $\begin{array}{l}\text { Classroom } \\
\text { Management }\end{array}$ & 2.169 & 2 & 1.084 & 1.066 & .345 \\
\hline \multirow{3}{*}{$\begin{array}{l}\text { Experience } \\
\text { (s1yr, 1-5yr, } \\
6-10 y r \& \\
\geq 10 y r)\end{array}$} & $\begin{array}{l}\text { Student } \\
\text { engagement }\end{array}$ & 9.058 & 3 & 3.019 & 3.408 & .018 \\
\hline & $\begin{array}{l}\text { Instructional } \\
\text { Strategies }\end{array}$ & 3.590 & 3 & 1.197 & 1.435 & .232 \\
\hline & $\begin{array}{l}\text { Classroom } \\
\text { Management }\end{array}$ & 6.380 & 3 & 2.127 & 2.106 & .099 \\
\hline \multirow{3}{*}{$\begin{array}{l}\text { Qualifications } \\
\text { (Postgraduate, } \\
\text { Trained } \\
\text { Graduates, } \\
\text { Trained, NCOE } \\
\text { teachers) }\end{array}$} & $\begin{array}{l}\text { Student } \\
\text { engagement }\end{array}$ & 1.684 & 4 & .421 & .466 & .761 \\
\hline & $\begin{array}{l}\text { Instructional } \\
\text { Strategies } \\
\end{array}$ & 2.388 & 4 & .597 & .712 & .584 \\
\hline & $\begin{array}{l}\text { Classroom } \\
\text { Management }\end{array}$ & 3.476 & 4 & .869 & .853 & .492 \\
\hline
\end{tabular}

To what extent does the PGDE programme help in developing knowledge and skills in terms of IS, CM and SE in their teaching and learning process?

PGDE student-teachers were asked whether the PGDE programme helped them to develop their knowledge and skills in terms of student engagement and in choosing and utilizing appropriate instructional strategies and techniques in classroom management. They were further asked about the courses of the programme that really helped them develop in these areas. $78 \%$ of the student teachers stated that they developed skills in these areas from the courses taught in the PGDE programme, particularly Educational 
Psychology, Educational Technology and the Teaching Practice components of the PGDE programme.

For example, one respondent from the Colombo Regional Center expressed his views as follows:

"...actually this programme was very useful for me to understand about methods and techniques as well as teaching aids thus I was able to conduct my lessons more effectively than before enrolled in the programme..."

Similarly, another respondent from Anuradhapura Regional Center stated as follows:

"...although I teach in my school for many years, I got to know the correct methods and techniques of teaching as well as developing a proper lesson plan after studying the subject educational technology of the PGDE programe..."

A majority (69\%) of the teachers said they did not know about specific teaching methodologies and techniques before following the PGDE programme.

Sixty two percent (62\%) of Tamil medium students requested the availability of audio-visual (AV) materials related to the programme in their language. For instance, a respondent from the Jaffna Regional Center mentioned the following:

"...though I come to know there are number of AV materials developed related to the programme, those are available only in main library which is far away from my center. Therefore, please make them available to access those in my center or via YouTube..."

According to the students, many of the materials were available only in Sinhala medium. Students from all media requested uploading of AV materials either on the university website or on the OUSL YouTube to make the AV materials accessible. A majority (73\%) of the student teachers suggested that more sessions on Educational Technology and for Teaching Practice to be conducted separately without reducing the existing number of day school sessions for the subject Educational Technology. These students have learned many techniques from their classroom practices in the Educational Technology courses and Teaching Practice. 


\section{Discussion}

Findings from the analysis of data revealed that the student teachers of the PGDE programme had developed positive self-efficacy beliefs in terms of student engagement, instructional strategies and classroom management. It clearly showed that the PGDE programme has contributed in the development of their self-efficacy beliefs. Further, experienced teachers differed significantly from other teachers in terms of student engagement self-efficacy.

The study provides several suggestions to enhance the PGDE Programme in order to enhance the student-teachers' self-efficacy. Major areas of the PGDE programme that are relevant to the self-efficacy of student-teachers is Educational Technology course and the Teaching Practice component. The number of Day schools and workshops for these two components must be increased as student-teachers get more knowledge and skills on instructional strategies and other domains of the self-efficacy beliefs. Further, additional learning materials, such as AV materials, especially in Educational Psychology, Educational Technology and Teaching Practice components, must be developed and provided in the students' native languages. These materials can be uploaded to the University website to promote ease of access by student teachers. The creation of an OUSL YouTube channel where all AV materials can be uploaded would improve accessibility. The selfefficacy beliefs of student-teachers in terms of experience are high in the case of student engagement. Thus, less experienced student-teachers can be grouped with more experienced teachers during the activities conducted at contact sessions to improve the self- efficacy of the former in the aspect of student engagement.

\section{Conclusions and Recommendations}

The self-efficacy of teachers refers to teachers' beliefs in their ability to organise and perform teaching-learning activities successfully. In this study, TSES instrument was administrated to determine PGDE student-teachers' self- efficacy beliefs. In addition, several open-ended questions were also added to find out whether the PGDE Programme contributes in the development of teachers' self-efficacy beliefs. One main conclusion from the study is that student teachers had high self-efficacy beliefs in their teaching and learning process. Student-teachers of the PGDE Programme did not 
differ significantly based on their medium of teaching, gender, qualifications but they differed significantly in terms of experience in the student engagement component of self-efficacy. Therefore, the study revealed that the PGDE Programme helped increase the self-efficacy of student- teachers to some extent.

The subjects of the PGDE programme, especially Educational Technology and Teaching Practice component, facilitated student-teachers to develop selfefficacy beliefs to a certain extent. However, it is essential to ensure that additional learning materials including audio-visuals be made available not only in the main library but also in all OUSL centres.

Although the PGDE programme is conducted in the open and distance mode, increasing day schools and workshops for the subject Educational Technology, which aims to train teachers to be successful in their teaching and learning, would be beneficial.

To gain a broader understanding of teachers' self-efficacy beliefs in the context of Sri Lanka, it is advisable to conduct similar studies focusing on a variety of PGDE programmes which are offered by other universities in Sri Lanka. Likewise, it can also be recommended that qualitative techniques, such as interviews and classroom observations, be employed along with the TSES instrument to determine student-teachers' self-efficacy beliefs.

\section{References}

Arigbabu, Abayomi A., I., D., \& Oludipe. (2009). Perceived Efficacy Beliefs of Prospective Nigerian Science Teachers. Journal of Science Education and Technology 19(1), 27-31. Retrived from https://link.springer.com/article/10.1007/s10956-009-9175-1

Bandura, A. (1977). Self-Efficacy: toward a unifying theory of behavioral change. Psychological Review 84, 191-215. Retrived from http://psycnet.apa.org/journals/rev/84/2/191/

Bandura, A. (1983). Self-efficacy determinants of anticipated fears and calamities. Journal of Personality and Social Psychology, 45, 464-469. Retrived From http://dx.doi.org/10.1037/0022-3514.45.2.464

Bandura, A. (1986). Social foundations of thought and action: A social cognitive theory. Englewood Cliffs, NJ: Prentice-Hall. 
Bandura, A. (1997). Self-Efficacy: The exercise of control. Newyork: W.H. Freeman \& Company.

Cantrell, P., Young, S., \& Moore, A. (2017). Factors Affecting Science

Teaching Efficacy of Preservice Elementary Teachers. Journal of Science Teacher Education, 14(3), 177-192. Retrived From http://dx.doi.org/10.1023/a:1025974417256

Cerit, Y. (2010). Teacher Efficacy Scale: The Study of Validity and Reliability and Preservice Classroom Teachers' Self Efficacy Beliefs. Journal of Theory and Practice in Education, 6 (1), 68-85.

Chang, Y. (2010). A Case Study of Elementary Beginning Mathematics Teachers' Efficacy Development. International Journal Of Science And Mathematics Education, 8(2), 271-297. Retrived From http://dx.doi.org/10.1007/s10763-009-9173-z

Charalambous, C., \& Philippou, G. (2010). Teachers' concerns and efficacy beliefs about implementing a mathematics curriculum reform: integrating two lines of inquiry. Educational Studies in Mathematics, 75(1), 1-21. Retrived from https://link.springer.com/article/10.1007/s10649-010-9238-5

Darling-Hammond, L. (1990). Instructional Policy Into Practice: "The Power of the Bottom Over the Top". Educational Evaluation And Policy Analysis, 12(3), 339-347. Retrived from http://dx.doi.org/10.3102/01623737012003339

Duffin, L.C., French, B.F., \& Patrick, H. (2012). The Teachers' Sense of Efficacy Scale: Confirming the factor structure with beginning preservice teachers. Teaching ad Teacher Education, 28(6), 827-834. Retrived From https://www.researchgate.net/publication/257246022_The_Teachers'_ Sense_of_Efficacy_Scale_Confirming_the_factor_structure_with_beginn ing_pre-service_teachers

Fives, H. (2003). What is Teacher Efficacy and how does it relate to Teachers' Knowledge? A Theoretical Review, Paper presented at the American Educational Research Association Annual Conference, April 2003 - Chicago. Retrived From http://citeseerx.ist.psu.edu/viewdoc/download?doi=10.1.1.135.6460\& $r$ ep=rep1\&type $=$ pdf

Flores, M. A. (2005). Teachers' Views on Recent Curriculum Changes: Tensions and Challenges. The Curriculum Journal 16 (3): 401-413. Retrived from http://www.tandfonline.com/doi/abs/10.1080/09585170500256479 
Friedman, I. (2003). Self-efficacy and burnout in teaching: the importance of interpersonal-relations efficacy. Social Psychology of Education 6(3), 191-215. Retrived from https://link.springer.com/article/10.1023/A:1024723124467

Gibson, S., \& Dembo, M. H. (1984). Teacher efficacy: A construct validation. Journal of Educational Psychology, 76 (4), 569-582. Retrived From http://dx.doi.org/10.1037/0022-0663.76.4.569

Gonsalkorale, L.R. (2016). Distance Education and it's Sri Lankan Context (in Sinhala), Colombo:Agahas Publishers.

Gunawerdena, C. Rupasinghe S., \& Zoysa T.S.V. (2010). Comparative Education and Educational Problems: Development \& Issues in Education in Sri Lanka, PGDE module, Faculty of Education, OUSL. Klassen, R. M., Tze, V. M. C., Betts, S. M., \& Gordon, K. A. (2010). Teacher Efficacy Research 1998-2009: Signs of Progress or Unfulfilled Promise? Educational Psychology Review 23 (1), 21-43. https://link.springer.com/article/10.1007/s10648-010-9141-8 Kotelawele, D. A., \& Samarasundara, N. (1986). Distance Education in Sri Lanka. Paper presented at the Proceedings of the Regional Seminar on Distance Education Bangkok, Thailand, November 26-December 3,1986. Retrived from http://files.eric.ed.gov/fulltext/ED290864.pdf\#page $=712$ Kurz, T. B., \& Knight, S. L. (2003). An Exploration of The Relationship Among Teacher Efficacy, Collective Teacher Efficacy, And Goal Consensus. . Learning Environments Research, 7(2), 111-128. Retrived from https://link.springer.com/article/10.1023/B:LERI.0000037198.37750.0e Lee, M.-H., \& Tsai, C.-C. ( 2008). Exploring teachers' perceived self-efficacy and technological pedagogical content knowledge with respect to educational use of the World Wide Web. Instructional Science 38 (1), 121. Retrived from https://link.springer.com/article/10.1007/s11251008-9075-4

Linnenbrink, E., \& Pintrich, P. (2010). The Role of Self-Efficacy Beliefs In student engagement and learning in the classroom. Retrieved from http://www.tandfonline.com /doi/abs /10.1080/105 73560308223

Ma, Yun-peng, Yin, H.-b., \& Tang, L.-f. (2009). Teacher receptivity to systemwide curriculum reform in the initiation stage: a Chinese perspective. Asia Pacific Educational Reveiw (10), 423-432. Retrived from http://www.academia.edu/9021642/Teacher_receptivity_to_systwide_ curriculum_reform_in_the_initiation_stage_A_Chinese_perspective Marshall, J. C., Horton, R., Igo, B. L., \& Switzer, D. M. (2007). K-12 Science And Mathematics Teachers' Beliefs About And Use Of Inquiry In The 
Classroom. International Journal of Science and Mathematics Education (2009) 7 (2), (575-596). Retrived from

https://link.springer.com/article/10.1007/s10763-007-9122-7

McCormick, J., \& Ayres, P. L. ( 2009). Teacher self-efficacy and occupational stress: A major Australian curriculum reform revisited. Journal of

Educational Administration 47(4), 463-476. Retrived from http://www.emeraldinsight.com/doi/pdfplus/10.1108/09578230910967 446

Nawastheen, F.M. (2014). Evaluating Geography Teachers' Concerns Towards the 5E Instructional Model in the Competency Based Curriculum Reforms of Sri Lanka, PhD Thesis, UKM.

Putney, L. G., \& Broughton, S. H. (2011 ). Developing Collective Classroom Efficacy: The Teacher's Role as Community Organizer Journal of Teacher Education 62 62(1), 93-105. Retrived from http://journals.sagepub.com/doi/abs/10.1177/0022487110381760

Richter, D., Kunter, M., Klusmann, U., Lüdtke, O., \& Baumert, J. (2011). Professional development across the teaching career: Teachers' uptake of formal and informal learning opportunities. Teaching And Teacher Education, 27(1), 116-126. Retrived from http://dx.doi.org/10.1016/j.tate.2010.07.008

Smolleck, L. D., Carla Zembal-Saul, \& Yoder., E. P. (2006. ). The Development and Validation of an Instrument to Measure Preservice Teachers' SelfEfficacy in Regard to The Teaching of Science as Inquiry Journal of Science Teacher Education 17(2), 137-163. Retrived from http://www.tandfonline.com/doi/abs/10.1007/s10972-006-9015-6

Sivri, H. \& Balcı, E. , (2015). Pre-service Teachers' Classroom Management Self-efficacy Beliefs, International Online Journal of Educational Sciences 7 (4), 37 - 50 Retrived from http://www.iojes.net/userfiles/Article/IOJES_1882.pdf e-service Teachers' Classroom Management Self-efficacy Beliefs

Tschannen-Moran, M., \& Woolfolk Hoy, A. (2001). Teacher Efficay: Capturing an elusive construct. Tecahing and teacher education, 17, 783-805. Retrived from http://mxtsch.people.wm.edu/Scholarship/TATE_TSECapturingAnElusiv eConstruct.pdf

Tschannen-Moran, M., \& Woolfolk Hoy, A. (2007). The differential antecedents of self-efficacy beliefs of novice and experienced teachers. . Teaching and Teacher Education, 23 (6), 944-956. Retrived from http://dx.doi.org/10.1016/j.tate.2006.05.003 
Tschnnen-Moran, M., Woolfolk Hoy, A., \& K.Hoy. (1998). Teacher Efiicacy: its meaning and measure. Reveiw of Educational Research 68(2), 202248. Retrived from http://mxtsch.people.wm.edu/Scholarship/RER_TeacherEfficacy.pdf

Woolfolk Hoy, A., \& Sperob, R. B. (2005). Changes in teacher efficacy during the early years of teaching: A comparison of four measures. Teaching and Teacher Education 21, 343-356. Retrived From http://www.sciencedirect.com/science/article/pii/S0742051X0500019 3

Woolfolk Hoy, A. (n.d.). Instruments, Retrieved From http://u.osu.edu/hoy.17/research/instruments/\#Ban 2017

Yeo, L. S., Ang, R. P., Chong, W. H., Huan, V. S., \& Quek, C. L. (2008). Teacher Efficacy In the Context of Teaching Low Achieving Students. . Curriculum Psychology 27, 192-204. Retrived from https://link.springer.com/article/10.1007/s12144-008-9034-x 